\title{
Do ponto de vista da espécie
}

\section{From the species point of view}

\author{
José Costa Jr.i \\ i Professor, Instituto Federal de Minas Gerais. \\ Ponte Nova - MG - Brasil \\ orcid.org/0000-0002-1117-4853 \\ jose.costajunior@yahoo.com.br
}

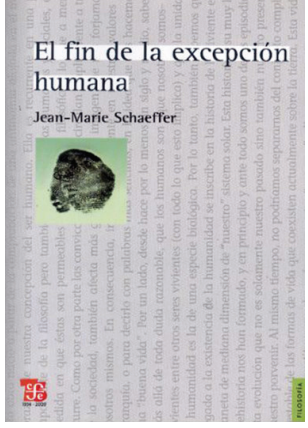

SCHAEFFER, Jean-Marie. El fin de la excepción humana. Trad. Victor Goldstein. Buenos Aires: Fondo de Cultura Económica. 2009. 324p.
Durante o desenvolvimento de sua hipótese sobre a origem da diversidade da vida, Charles Darwin passou a conceber uma possibilidade estranha ao seu tempo: a ideia de que os seres humanos seriam integrantes do reino animal, numa existência passível de explicação "natural". Identificou o conjunto de questões que essa possibilidade abriria como "metafísica da moral": "O homem viria de macacos?" - questionou a si mesmo. E respondeu: "O homem em sua arrogância pensa em si como uma obra grandiosa, digna da intervenção de uma divindade. É mais humilde - e mais verdadeiro, acredito - considerar que foi criado a partir de animais" (Darwin citado em Browne, 2007, p.50).

Para muitos, a visão darwiniana o aproximava (e ainda aproxima) perigosamente de uma filosofia materialista, doutrina de ordem metafísica que busca explicar a natureza geral da realidade desconsiderando forças sobrenaturais. Darwin identificou dúvidas e questionamentos sobre as implicações antropológicas de sua hipótese como "tumultos morais". Tais tumultos envolviam questões antropológicas de fundo, como o lugar da liberdade, do pensamento e da moralidade. Se somos "apenas animais", como explicar as características distintivas da humanidade? Não seremos mais dignos de consideração e respeito? Como explicar o sentido da realidade e de nossa existência sem quaisquer referências a ordens que nos transcendem?

Conforme o filósofo francês Jean-Marie Schaeffer (1952-), essa tensão não ficou restrita ao tempo de Darwin e nem aos círculos religiosos. Em El fin de la excepción humana, Schaeffer (2009) argumenta que, mesmo passado mais de um século e meio da publicação de $A$ origem das espécies, muitos de nós ainda nos mantemos desconfortáveis com as implicações da hipótese darwiniana para a compreensão da humanidade. No entanto, o que mais surpreende é que até mesmo os especialistas em ciências humanas, aqueles que buscam ampliar a compreensão acerca do que somos e como vivemos de um ponto de vista laico, tendem a se afastar e revisar hipóteses antropológicas que envolvam a compreensão 
darwiniana sobre a vida e a humanidade. Essa negação se transmite para a visão comum que temos de nós mesmos e até para a compreensão geral de práticas científicas sofisticadas, como medicina e psicologia, configurando um cenário paradoxal.

El fin de la excepción humana foi publicado originalmente na França, em 2007, e tem como objetivo principal analisar e compreender as razões do ceticismo e distanciamento em relação a abordagens naturalistas da humanidade. Para além da resistência religiosa, o autor identifica posições filosóficas que sustentaram quadros descritivos sobre a humanidade que são questionáveis do ponto de vista das ciências da vida na contemporaneidade. A consequência maior dessa negação seria uma descrição limitada do "animal humano", com desdobramentos relevantes para a compreensão acerca do que somos e como vivemos.

O livro contém seis capítulos, mas também pode ser dividido entre uma parte filosófica (os dois primeiros e o último capítulo), na qual o autor apresenta e discute conceitos de forma organizada e informativa, e uma parte mais científica (o terceiro, o quarto e o quinto capítulos), em que temos uma apresentação de dados e informações oriundas de diversas áreas da investigação científica, como biologia, psicologia, neurociências e outras.

O autor começa por descrever o que chama de a tese da exceção humana, fundada em quatro pilares conectados entre si: (a) a ideia de que o humano é um ser não natural, cenário que aponta para (b) um dualismo ontológico, que estabelece uma (c) ruptura ôntica entre humano e mundo e que possibilita (d) um gnoseocentrismo antinaturalista, a ideia que sustenta a essência humana da atividade teorética, concebendo o sujeito humano como pensamento puro, exterior ao mundo e superior a ele.

A partir disso, Schaeffer propõe o que chama de desescalada ontológica, um movimento contrário a "escalada ontológica", uma tentação filosófica comum de buscar explicações ontológicas últimas e fundacionais, que pode ser exemplificada a partir da filosofia de René Descartes. Para isso, propõe uma "abordagem mesocognitiva", a fixação da questão do humano em um nível mesocósmico, abordando o humano como uma forma de vida entre outras, fixando-o na evolução das formas de vida biológica na terra.

As ciências empíricas nos informam cada vez mais acerca das origens e de outros traços da nossa espécie, o que Schaeffer identifica como "animalidade da humanidade". Tais informações nos ensinam sobre a vida, sua reprodução e seu desenvolvimento, e também sobre os fatores causais da evolução das formas de vida, conjunto no qual estamos inseridos. Essas descobertas trazem implicações relevantes para a compreensão que temos de nós mesmos (principalmente em relação ao antropocentrismo).

Um dos principais elementos distintivos da humanidade seria a possibilidade de uma vida social organizada e diferenciada. O "homem como ser social" parece escapar a explicações evolutivas e naturalistas, mas Schaeffer mostra a diversidade de cenários possíveis em termos evolutivos que podem explicar esse traço. Além disso, aponta para o fato de sermos "mais uma espécie social", com sistemas e determinantes próprios para essa distinção.

Outro traço distintivo da humanidade é a presença de cultura. A variedade cultural observada na espécie humana é um dos marcos da tese da exceção, pois supostamente evidencia como nos separamos do mundo natural. Schaeffer aborda diversas explicações naturalistas-evolutivas para explicar as formas de aquisição, transmissão e difusão de cultura, além de um quadro mais amplo sobre possibilidades de explicações genealógicas. 
Como último desafio, Schaeffer aborda a questão da consciência humana. Descreve o estado da arte das investigações científicas sobre o tema, mas sugere que a abordagem essencialista do tema ainda é um resquício da tese da excepcionalidade humana. Por fim, trata também da tensão que percorre o livro, entre saberes empíricos e visões de mundo, ampliando a discussão sobre como as pesquisas científicas vão aos poucos impactando nossas crenças sobre nós mesmos e sobre a realidade.

El fin de la excepción humana é uma obra relevante para entendermos as bases e implicações da ainda "perigosa ideia de Darwin". Perdidos entre reducionismos genéticos e comportamentais ingênuos - que Schaeffer desqualifica no livro - e reacionarismos pouco informados - como a hipótese do "desenho inteligente" -, precisamos cada vez mais de reflexões "do ponto de vista da espécie", que nos ajudam a compreender e a intervir naquilo que somos e em como vivemos.

\section{REFERÊNCIAS}

BROWNE, Janet.

A "Origem das espécies" de Darwin: uma biografia. Rio de Janeiro: Jorge Zahar. 2007.
SCHAEFFER, Jean-Marie.

El fin de la excepción humana. Trad. Victor

Goldstein. Buenos Aires: Fondo de Cultura

Económica. 2009. 